\title{
THE TOUCHABLES: VICE AND POLICE CORRUPTION IN THE 1980'S
}

\author{
JOHN DOMBRINK*
}

\section{INTRODUCTION}

\section{A. The Recent Wave of Police Corruption}

In the midst of a federal investigation that resulted in the conviction of thirty-one Philadelphia police officers, the Philadelphia Inquirer, which referred to the city as a "petri dish for corruption,"1 described the elements that made Philadelphia one of the leading examples of systemic police corruption in recent years. A hierarchical and lucrative system of payoffs from pimps, video gambling machine purveyors, and numbers operators cut through several layers of the police force, extending as far as the second-in-command of the entire city. ${ }^{2}$ Through a series of federal investigations and prosecutorial efforts that netted several high-ranking police officers, some of whom turned state's evidence and broke what the chief prosecutor called the conspiracy of silence, the Philadelphia situation was brought to the forefront in a country which had experienced several significant police scandals in recent years. As the chief prosecutor explained, "[t]he message has been sent that officers cannot trust anyone to insulate them from the consequences of their wrongdoing." 3

In other major American cities, corruption episodes were also coming to the attention of authorities. In New York City, several members of the 77th Precinct were indicted after they were suspected of extorting money from crack dealers. ${ }^{4}$ In Boston, officers were convicted of activities including extorting payoffs from vice purveyors. ${ }^{5}$ In San Francisco, an initiation

\footnotetext{
Copyright (C) 1988 by Law and Contemporary Problems

Assistant Professor, Program in Social Ecology, University of California, Irvine.
}

My gratitude to John Kaplan for suggesting this timely yet enduring title. I would like to thank the UCI students who assisted in this project: Shari Moskau, Logan Morff, Tony Choi, Sashi Muralidharan, John Lewin, James Parsa, Lori Flournoy Rahmann, Angelo Duplantier, Hilda Burgos, and Lion Jacobs. I am also grateful to the attendees of the Law and Contemporary Problems Conference on Vice at Duke Law School for their insights and suggestions, especially Jerome Skolnick, John Kaplan, Phil Cook, Mark Kleiman, and Peter Reuter. My thanks also to Jerry Caplan, Howard Klein, Ian Lennox, and J. Clayton Undercofler III for their advice and assistance.

1. Lopez, The Good Guys in This Town, Philadelphia Inquirer, Nov. 28, 1986, at B1, col. 1.

2. Klein, Fighting Corruption in the Philadelphia Police Department: The Death Knell of the 'Conspiracy of Silence,' 60 TEMPLE L. Q. 103 (1987).

3. Id. at 115 .

4. N.Y. Times, Sept. 26, 1986, at B1, col. 1; M. McAlary, Buddy Boys: When Good Cops Go BAD (1987).

5. Doherty, Vest Found Guilty on 2 Perury Counts, Boston Globe, Oct. 7, 1986, at 1, col. 2. 
ceremony for a rookie police officer that included the services of a prostitute was among several key events that forced that city to reexamine some of the controls it maintained over its police force. ${ }^{6}$ In Miami, where the onslaught of drug importation in the last decade has inexorably changed the nature of the community to one reminiscent of the Wild West, a ring of police officers was tried for running a drug distribution enterprise. ${ }^{7}$

In many ways, the forms the examples noted above took were either predictable or routine. For instance, while the Philadelphia example was noteworthy for the extent of its operation and the success of the prosecutorial team in gaining cooperation from insiders, ${ }^{8}$ the extortion schemes themselves were fairly traditional forms of shakedowns from that frequent victim, the illegal gambler. Amidst the third wave of legalization of gambling in this country, which saw the approval of casinos in one state, ${ }^{9}$ horse racing in several states, ${ }^{10}$ and lotteries in many others, ${ }^{11}$ the meaning of the Philadelphia example is difficult to discern. We are thrown back to the insights of Gardiner, who found in Wincanton the apparent contradiction among the residents there who were tolerant of illegal gambling, but alarmed and disapproving toward the police corruption that ensued from the implementation of such a policy of tolerance. ${ }^{12}$

In Miami and New York City, the cocaine-related cases, coming at a time when the country has devoted significant financial and emotional resources to curtailing the flow of illicit drugs into the country, are of great import. ${ }^{13}$ The five cases, Philadelphia, New York City, Miami, Boston, and San Francisco, taken together represent a sample of the types of police corruption issues related to vice that have developed in the past decade. They have done so against a backdrop of increased gambling legalization, ${ }^{14}$ increased use of cocaine and debate over its decriminalization, ${ }^{15}$ a prostitute rights movement, ${ }^{16}$ bitter debate over the abortion laws, ${ }^{17}$ discussion of pornography and its effects, ${ }^{18}$ and increased use of marijuana and heroin. ${ }^{19}$

6. Interview with David Ambrose, San Francisco Police Department Public Affairs Officer (Apr. $27,1987)$.

7. L.A. Times, Jan. 22, 1987, at I14, col. 1.

8. Klein, supra note 2 , at 115 .

9. J. Dombrink \& W. Thompson, The Last Resort: Success and Failure in Campaigns for CASINOS (forthcoming, 1989).

10. Id.

11. Id.

12. J. Gardiner, The Politics of Corruption: Organized Crime in An American City 55 (1970).

13. J. Dombrink \& J. Meeker, Criminal Capital: Making Organized Crime Unprofitable (forthcoming, 1989).

14. V. Abt, J. Smith \& E. Christiansen, The Business of Risk: Commercial Gambling in Mainstream AMERica 193 (1985).

15. L. Grinspoon \& J. Bakalar, Cocaine: A Drug and Its Social Evolution (1985).

16. R. Weitzer, "Immoral Crusade": The Prostitutes' Rights Movement in the United States (1987) (unpublished manuscript).

17. K. Luker, Abortion and the Politics of Motherhood (1984).

18. E. Donnerstein, D. Linz \& S. Penrod, The Question of Pornography: Research Findings and Policy Implications (1987).

19. E. Schur, The Politics of Deviance: Stigma Contests and the Uses of Power (1980) 
Moreover, these examples have happened at the same time as a number of changes in the operation of police departments ${ }^{20}$ and as interventions in police departments taken to prevent and discover police corruption ${ }^{21}$ have been spawned.

For virtually thè entire existence of the urban American police force, situations involving vice and its control have presented opportunities for corruption and posed a challenge to police administrators who hoped to limit their officers' misconduct without alienating the officers' loyalties. ${ }^{22}$ Vice creates many police problems, not only those which are corruption related. Resource allocation is naturally complicated by the need to respond to disorderly situations or other complaints. ${ }^{23}$ Misconduct as serious as perjury can be undertaken in vice circumstances to circumvent procedural due process in situations which are otherwise serving organizational goals. ${ }^{24}$ Vice control combines the often critical mandate for order maintenance functions of policing with the low seriousness assigned most vice offenses. ${ }^{25}$ That sort of conflict is rarely found in other activities. Police, like other bureaucratic actors, are naturally concerned with achievement of their performance criteria. The clearance rate of vice arrests (the percentage of successful prosecutions or arrests) is too small either to please administrators or to assuage the concerns of a public threatened by the perception of high and increasing crime rates.

The ambivalence of vice control, a confusion created by the contradictory messages American citizens send to their police, has created several persistent moral, legal, and organizational dilemmas for American police departments. ${ }^{26}$ If the police were to pursue policies of total enforcement, the work could consume the available resources of police agencies, preventing them from devoting even minimal effort to the policing of more serious crimes and the processing of mundane citizen complaints. Moreover, as Gardiner and others have shown, while corruption and vice feed from each other, Americans have shown a strong dislike for the one while tolerating the other. ${ }^{27}$ At a time when vice is perceived as rising, and when the expense of both traditional and innovative policing strategies is significant, especially in fiscally strained, viceimpacted urban centers, new events and situations have amplified these

20. J. Skolnick \& D. Bayley, The New Blue Line: Police Innovation in Six American Cities (1986)

21. See generally A. Kornblum, The Moral Hazards: Police Strategy for Honest and Ethical Behavior (1976); M. Punch, Conduct Unbecoming: The Social Construction of Police Deviance and Control (1985); L. Sherman, Scandal and Reform: Controlling Police CORRUPTION (1978).

22. Skolnick, Police: Vice Squad, in 3 Encyclopedia of Crime and Justice 1148, 1151-53 (S. Kadish ed. 1983).

23. See J. Wilson, Varieties of Police Behavior 83-139 (1968).

24. M. PUNCH, supra note 21, at 13-14.

25. Bureau of Justice Statistics, Report to the Nation on Crime and Justice: The Data 4, 5 (1984).

26. Skolnick, The Social Transformation of Vice. Law \& Contemp. Probs., Winter 1988, at 9.

27. J. GARDINER, supra note 12 , at 55-56. 
concerns, created complicated dilemmas, and generally added to the complexity of vice control.

Studies analyzing the role of corruption in effecting organizational reform indicate that, despite the substantial attention which scandals attract, the conditions and costs of reforming corrupt police departments for any mêäningful length of time are so great that the mere fact of scandal is not enough to ensure subsequent reform. ${ }^{28}$ Nonetheless, the lull in American police corruption after the well-publicized Knapp Commission report ${ }^{29}$ and the Special Investigations Division scandal $^{30}$ seemed to represent the resolution of endemic problems associated with vice and police corruption. Coming at the end point of this lull, however, the series of scandals in five major American police departments called into question the effectiveness of existing internal organizational controls as well as external monitoring processes. Despite commitment of extensive federal law enforcement resources and the "moral equivalent of war" applied to the control of illicit drugs, the persistence of vice presented continued opportunities for wrongdoing. ${ }^{31}$ Moreover, the form and opportunities for corruption shifted.

Nine years ago, the trend toward legalization of vice appeared as though it would have a profound effect on society, and scholars suggested a variety of rationales and a number of models for legal regulation and control of various forms of vice. ${ }^{32}$ In the intervening years, however, a great impact on society and the legal system by vice-related.issues has occurred, but arguably more in the nature of confounding and contradictory effects. Marijuana causes little concern, but government agencies reward agents for building marijuana cases. $^{33}$ Heroin is considered serious, and efforts to control street-level dealing seem to have an effect on the heroin market. ${ }^{34}$ Prostitution is usually assigned low priority for policing, but the disorderly aspects of it sometimes make for public uproar. Legal gambling has grown dramatically over the past decade, yet other forms of gambling are resisted, due to possible problems. ${ }^{35}$ Nowhere is this combination of mixed messages and mixed results of more

28. L. Sherman, supra note 21 , at 242-63.

29. The Knapp Commission Report on Police Corkuption (1973).

30. M. PunCH, supra note 21, at 25-27.

31. See generally Reuter, Quantity Illusions and Paradoxes of Drug Interdiction: Federal Intervention into Vice Policy, Law \& Contemp. Probs., Winter 1988, at 233; M. Kleiman, Drug Enforcement and Organized Crime: Current Knowledge and Research Prospects (1985) (unpublished manuscript prepared for symposium sponsored by Northwest Policy Studies Center, Dulles International Airport, Virginia, Sept. 25-26, 1986); Kleiman \& Reuter, Risks and Prices: An Economic Analyis of Drug Enforcement, 7 Crime \& Just. 289 (1986)

32. See, e.g., J. Kaplan, Marijuana: The New Prohibition (1970); J. Skolnick, House of Cards: The legalization and Control of Casino Gambling (1978); Skolnick \& Dombrink, The Legalization of Deviance, 16 CRIMINology 193, 198-206 (1978).

33. M. Kleiman, Allocating Federal Drug Enforcement Resources: The Case of Marijuana 179 (1985) (unpublished doctoral dissertation, John F. Kennedy School of Government, Harvard Univ.).

34. J. Kaplan, The Hardest Drug: Heroin and Public Policy 79, 83 (1983); see also Street-Level Drug Enforcement (National Institute of Justice video crime film series 1986).

35. J. Dombrink \& W. Thompson, Riding the Crest of the Third Wave: Illegal and Legal Gambling Policies in America (1985) (unpublished manuscript prepared for the President's Commission on Organized Crime). 
significance than in the ability of police departments to effectively deploy strategies of corruption control at the same time as they pursue crime-fighting techniques. In fact, some of the reforms aimed at deterring police corruption, such as rotating police in their precinct assignments, are directly at odds with some of the premises of the resurgence of community-based policing norms. How the events of the last decade and the policing challenges of the next decade have been affected by vice development will be examined below.

\section{B. The Changing Patterns of Vice}

During the 1960's, many prominent legal scholars argued against the wasteful use of the crime-fighting resources in enforcing virtually unenforceable laws in the area of vice. ${ }^{36}$ From Packer's admonition to guard against exceeding the limits of the criminal sanction ${ }^{37}$ to Kadish's ${ }^{38}$ and Allen's ${ }^{39}$ discussion of the unique properties of enforcement at the fringes of the criminal law, various legal scholars rallied against the use of the criminal sanction to legislate morality. Some followed Mill's notion that state intervention in such areas was not compelled, ${ }^{40}$ while others, such as Packer ${ }^{41}$ and Skolnick, ${ }^{42}$ espoused the view that the impracticality of such laws was of paramount concern.

Cocaine's passage from a rarely used, elitist, and little understood drug in the early 1970's to a more widely used substance by 1988 has brought to the foreground many complex and contradictory factors. As late as 1985, Americans responding to an American Broadcasting Company ("ABC") poll, overwhelmingly (92 percent to 6 percent) rejected the notion of making possession of small amounts of cocaine for personal use legal. ${ }^{43}$ Yet, cocaine use was the fastest growing illegal drug use during this period. ${ }^{44}$ One has to go back ten years to find a time when fewer Americans favored either legalizing the use of marijuana or removing criminal sanctions on its possession. ${ }^{45}$ At the same time, six or seven respondents to the $\mathrm{ABC}$ poll thought that "[d]rug abuse will never be stopped because a large number of

36. See infra notes 37-39.

37. H. Packer, The Limits of the Criminal Sanction 250 (1968).

38. Kadish, The Crisis of Overcriminalization, 374 AnNals 157, 164-65 (1967).

39. F. Allen, The Borderland of Criminal Justice: Essays in Law and Criminology 7-9 (1964).

40. J. Mill, ON Liberty 100 (C. Shields ed. 1 lth printing 1956) (1st ed. 1859).

41. H. PACKer, supra note 37, at 261-69.

42. Skolnick, Coercion to Virtue: The Enforcement of Morals, 41 S. CAL. L. Rev. 588, 632 (1966).

43. ABC News/Washington Post Poll, May 1985.

44. J. Polich, P. Ellickson, P. Reuter \& J. Kahan, Strategies for Controlling Adolescent Drug USE 33 (1984). The misidentification of cocaine as a narcotic and its identification as a dangerous drug has persisted from the early twentieth century, even though widespread use might somewhat mollify this notion. L. Grinspoon \& J. BakAlar, supra note 15, at 211-237. The emergence of crack as a more volatile concoction of cocaine reinforced this idea in the mid-1980's. Kerr, Use of Crack: The Future, N.Y. Times, Sept. 1, 1986, at 25, col. 5. Moreover, cocaine is considered more a recreational drug than one likely for medicalization. L. Grinspoon \& J. BAKALAR, supra note 15 , at 238-67.

45. The Gallup Poll, June 20, 1985. 
Americans will continue to want drugs and be willing to pay lots of money for them." 46

The generational patterns of familiarity and use, and the inability of Americans to decide whether cocaine is in fact a soft or hard drug, have created a stratified response to policy issues in this area. ${ }^{47}$ While the polls cited above may indicate otherwise, the perception of cocaine has been increasingly separated from the stigma attached to heroin. Naturally, some of the disreputability of a drug is a result of the status of the average user. Cocaine has long been billed as an affluent drug, ${ }^{48}$ a feature which has gained it some positive status but also provides an obstacle against widespread social acceptance. In any case, its use more closely parallels that of marijuana, rather than heroin, and thus it has avoided some of the traps associated with the latter.

At the same time as patterns of drug perceptions were changing, the number of legal abortions grew annually, and even conservative groups were in favor of the liberalized abortion laws established by Roe v. Wade. ${ }^{49}$ Gayrights groups had been successful in advancing the passage of more than fifty state, county, and local ordinances prohibiting discrimination on the basis of sexual orientation. ${ }^{50}$ In addition, gay and lesbian activists in several large American cities had become articulate political actors and effective political constituencies. ${ }^{51}$ At the same time, the growth in legal gambling has taken place against a curious situation regarding illegal gambling prevention. The federation of gambling control52 in the 1970's reduced many of the temptations related to local responsibility for policing, but has not reduced police perception of links between illegal gambling and organized crime. ${ }^{53}$ Vice has become at once more politicized, more subsumed under expectations of civil rights, more commercialized, more available to ordinary Americans, and essentially more ambivalent over the past decade.

In Skolnick's words, ever present public ambivalence has been reinforced. ${ }^{54}$ Measures to reduce or control police corruption are needed for many reasons. For one thing, the reaction of citizens to police and their performance and legitimacy may be predicated upon their perceptions of police corruption. To the extent that citizens, particularly in high-crime, vice-

46. ABC News/Washington Post Poll, supra note 43.

47. L. GRINSPOON \& J. BakAlaR, supra note 15, at 211-37.

48. Id. at $58-63$.

49. Roe v. Wade, 410 U.S. 113 (1973).

50. Meeker, Dombrink \& Geis, State Law and Local Ordinances in California Barring Discrimination on the Basis of Sexual Orientation, 10 U. Dayton L. Rev. 745, 756 (1985).

51. D. Altman, The Homosexualization of america: The americanization of the Homosexual 109-45 (1982).

52. P. Reuter, Disorganized Crime: The Economics of the Visible Hand 177-81 (1983).

53. Pratter \& Fowler, Police Perceptions about Gambling Enforcement: A National Survey of Law Enforcement Agencies, in Gambling in America, at 461, 464, app. 1 (1976) (Report of the Commission on the Review of the National Policy Toward Gambling); J. Meeker \& J. Dombrink, Bookies and Bosses: Illegal Gambling and Legalization Efrorts 86 (1988) (proceedings of the Seventh International Conference on Gambling and Risk-Taking).

54. Skolnick, supra note 26 , at 12. 
impacted areas, think less of their police force, civic cooperation might be reduced on more serious investigations. This conundrum will be examined in the five case studies below.

\section{II}

\section{MiAmI}

"Miami Vice" may be a stylized and sensationalized television show, but the scenes portrayed have their basis in the reality of the past ciecade's drug wars. While the police in "Miami Vice" are generally noble and full of integrity, the reality in Miami has often been otherwise. In numerous examples, federal, state, and local law enforcement officers have fallen prey to the lure of drug-related payoffs. ${ }^{55}$ The temptations are ever present and sizeable. As one high-ranking police officer observed, "[i]t's not unusual for a police officer to stop a car in a routine traffic violation and find $\$ 20,000$ in cash." 56 The price of a kilogram of cocaine is almost the same as a Miami police officer's annual salary. ${ }^{57}$

As "Miami Vice," numerous news shows, and a spate of new journalistic accounts have emphasized in recent years, Miami has become the illicit drug capital of the United States. ${ }^{58}$ The responsibility of policing such an area has fallen primarily on the shoulders of federal interagency task forces, but has also extended over to the local police forces in the South Florida region. In the last decade, a number of law enforcement officers at all levels have been . convicted of misconduct related to the drug business. ${ }^{59}$ According to one report, 100 of the 1060 Miami police officers have been, or are currently being, investigated on corruption-related matters, and officials are predicting that as many as 200 officers may face investigation. ${ }^{60}$

In Miami, the indictment of seven officers, known as the River Cops or the Enterprise, revealed that they had started by stealing drugs from motorists stopped for traffic violations and worked their way up to major rip-offs. ${ }^{61}$ Informants would reveal the location of million-dollar loads of cocaine, and the police officers would steal the drugs instead of arresting the dealers. ${ }^{62}$ They were indicted, but the jury deadlocked in their first trial. After that, a new series of indictments has targeted twenty officers, including the first

55. Stanford, Drugs and the Law, 470 Rolling Stone 64 (Mar. 27, 1986).

56. Nordheimer, Police Comuption Plaguing Florida, N.Y. Times, Aug. 3, 1986, at 19, col. 1.

57. Peterson, Miami Virtue, or Vice?, Wash. Post, Jan. 12, 1986, at Al, col. 4.

58. Rothchild, Crime Stoppers Notebook, 470 Rolling Stone 61 (Mar. 27, 1986).

59. Volsky, Wide Miami Inquiry into Police Is Seen, N.Y. Times, Dec. 13, 1987, at 29, col. 1 According to the U.S. Attorney for the Southern District of Florida, Leon Kellner, "the Miami Police Department has an extraordinarily serious problem, equal or surpassing anything I've seen anywhere. Unfortunately, our probe is mushrooming and we could end up with the largest police corruption case in United States' history." Id.

60. Id.

61. Bearak, Miami Seeking Answers and Police Trial Unfolds, L.A. Times, Oct. 6, 1986, at 4, col. 1.

62. Id. 
group of defendants. ${ }^{63}$ Six of the twenty were fugitives from justice in August 1987.

The Miami River Police Case is presumably not the end of the corruption probe, nor the only instance of finding police gone bad. Recently, in Miami, an FBI agent pled guilty to accepting cocaine kickbacks; ${ }^{64}$ and three Miami pólice officers were each charged with three counts of first-degree murder for their roles in a drug execution. ${ }^{65}$ Authorities have yet to catch the person(s) who stole $\$ 150,000$ from the safe at the headquarters office of the Miami police vice squad, as well as the thief of a quarter of a ton of marijuana from a supposedly secure place in the Miami Police Department Compound. ${ }^{66}$ In February 1986, a police officer in nearby North Bay Village was arrested for allegedly selling protection to FBI agents posing as drug dealers. ${ }^{67}$

To fight the corruption in South Florida, an FBI corruption squad has been in operation for several years. Federal initiative in this matter follows a series of failed state investigations into Miami area police corruption. ${ }^{68}$ One group is working on corruption in local zoning processes, including one case where an officer is accused of racketeering, bribery, and conspiracy to murder. ${ }^{69}$ In all, twenty-six agents are assigned to corruption. Several are Spanish-speaking agents who have worked on police corruption cases in other cities. Across town, IRS agents are tracking the assets of suspect police officers and filling in the financial gaps of suspects in a variety of corruption investigations. ${ }^{70}$ Another group of federal agents is investigating prominent Miami businessmen suspected of corrupting police with gifts and money. ${ }^{71} \mathrm{~A}$ swelling intelligence base is adding to the driving force of these. investigations. When the corruption unit began in 1983, very little information was available on the web of relationships that facilitate corruption in Dade County; the body of knowledge about how things work in Miami has grown significantly. The FBI and other agencies are thus able to target entire networks of corruption. A team of agents and prosecutors can react effectively to the informant or witness who comes forward with a story about a bribe paid for a zoning decision or a shakedown by a crooked cop.

Some of the issues generated by the Miami scandal have been the influence of youthfulness among police officers and attempts to achieve racial diversity in the police force amid rapid expansion. At the same time, the Miami Police Department was described as "overwhelmingly young and

63. Volsky, supra note 59.

64. Stanford, supra note 55 , at 66 .

65. Id.

66. Id.

67. Id.

68. McGee \& Leen, Feds Assault High-Level Corruption in S. Florida, Miami Herald, Nov. 16, 1986, at IA, col. 1 .

69. Id.

70. Id.

71. Id. 
inexperienced." 72 Moreover, the police force had grown from 650 officers in 1980 to 1033 officers in 1985 . One reason for the growth was the heavy influx of Cuban refugees to Miami in 1980, the year of the Mariel boatlift from Cuba. That event led to the resettlement of 100,000 Cubans, many with criminal records or other antisocial histories. ${ }^{73}$ Promoted by the Liberty City uprising of the early 1980's, among other influences, Miami police began to rapidly absorb many new recruits from minority groups. ${ }^{74}$ Later, when the River Police Scandal unfolded, and all the suspects were either black or latino, one police administrator noted, "[a] lot of people resistant to affirmative action are using the arrests of Hispanic officers as a subterfuge . . [to attack minority hiring programs.]"75

The Miami River Police case will probably come to trial again in 1989. Temptations related to the enormous drug traffic remain, and the unique demands of policing a biracial city continue to pose challenges for the coming decade. ${ }^{76}$ How the Miami police rebound from the River Police case will depend on larger efforts of drug interdiction, and site-specific issues of recruiting from and policing a culturally diverse community.

\section{III}

\section{Philadelphia}

The unprecedented federal prosecutions of systemic corruption in the Philadelphia Police Department, including convictions of more than thirty officers, revealed a deep-rooted structure, primarily centered on gamblingrelated misconduct, that reached as high as the second-in-command in the police department. ${ }^{77}$ Far from an isolated example, the Philadelphia cases revealed sophisticated networks of corruption grafted on to the police command structure itself. According to federal prosecutor Howard Klein, who personally tried twenty-two of the convicted police officers, "I think we proved the depth and prevalence of corruption at the department, and this led the city to reexamine the department and begin an extensive reform to prevent the recurrence of institutionalized corruption."78 The creation of a stronger anti-corruption mechanism was a recommendation of the Report of the Philadelphia Police Study Task Force, ${ }^{79}$ headed by Professor Gerald

72. Ingwerson, Miami Grapples with Allegations of Police Comption, Christian Science Monitor, Jan. 13, 1986, at 1, col. 2.

73. See generally D. Rieff, Going to Miami (1987); T. Allman, Miami: City of the Future (1987).

74. Nordheimer, Miami Police Scandal Raising Questions on Minority Recruits, N.Y. Times, Jan. 9, 1986 , at 10 , col. 1 .

75. Id. at col. 3.

76. D. RIEFF, supra note 73.

77. U.S. Government Sentencing Memorandum, U.S. v. Martin, No. 84-00106 (E.D. Pa. Sept. $21,1984)$.

78. Interview with Howard Klein, former federal prosecutor, Philadelphia (Mar. 19, 1987).

79. Philadelphia Police Study Task Force, Philadelphia and Its Police: Toward a New Partnership (1987). 
Caplan. ${ }^{80}$ The report, issued in March 1987, characterized the Philadelphia Police Department as "unfocused, unmanaged, under-trained, underequipped and unaccountable." 81 The report attributed the sorry state of the Philadelphia Police Department to a combination of community neglect and management failure. In a particularly trenchant summary; the Caplan report concluded that, " $[t]$ he dead hand of past traditions guides the department rather than the challenge of the future. A history of favoritism, corruption and brutality hangs over it." 82

The public response to police corruption and performance generally, as measured by a poll for the Philadelphia Police Study Task Force in 1986, ${ }^{83}$ indicated that the Task Force's assessment had to take into account a curious and often contradictory approach by Philadelphia residents to their police. Seventy percent of city residents responding to a poll taken for the Philadelphia Police Study Task Force rated the Philadelphia police as doing a good or excellent job overall. One apparent reason was that the force, the largest force per capita of America's ten largest cities, responded to over three million calls for service in 1985 , an average of nearly two calls per resident. ${ }^{84}$ A majority of residents had a high regard for the police profession, but at the same time felt that Philadelphia police were underenforcing some types of laws, especially in the areas of drugs and prostitution. Fully 69 percent of the respondents thought that the law on drugs is underenforced, 56 percent thought laws on prostitution were so treated, and 49 percent considered gambling laws underenforced. ${ }^{85}$ Eighty-one percent of residents describe their police as being honest, but roughly half thought the police to be discourteous. ${ }^{86}$ By far, the most striking results were related to how Philadelphia residents felt their police were rated regarding illegal and nonprofessional behavior. Almost half of the respondents felt that Philadelphia police engaged in some form of illegal or unprofessional behavior sometimes or often, including a remarkable 32 percent who believed the police used illegal drugs on duty. ${ }^{87}$

One of the Philadelphia Police Department's significant attempts to redress the corruption problems was to appoint Philadelphia-based United States Secret Service official Kevin Tucker as the Philadelphia Police Chief in January 1986. Part of Tucker's attraction lies in his status as an outsider. Unlike many of his predecessors and other possible commissioner candidates, Tucker had little personal or professional incentive to protect corruption within the department, and he was not in debt to any of the ranks below him. Tucker initiated a number of actions directed against corruption, some soon

80. Professor of Law, George Washington University Law School.

81. Philadelphia Police Study Task Force, supra note 79, at 16.

82. Id. at 17.

83. Id. at 16-17.

84. Id. at 21-23.

85. Id. at 168 .

86. Id. at 169 .

87. Id. at 170 . 
after his appointment. He established review boards to depoliticize promotions and transfers within the police department. ${ }^{88} \mathrm{He}$ also shifted the assignments of the top police commanders and reassigned hundreds of midlevel commanders. ${ }^{89}$ The new commissioner ordered the department to begin a field associates program, using new recruits to report incidents of police corruption they might witness, ${ }^{90}$ Tucker also reestablished foot patrols, in neglected neighborhoods to restore the bond between communities and police. ${ }^{91}$ To reduce police abuse of citizens, Tucker issued guidelines for the use of night sticks and ordered that the Internal Affairs Division ("IAD") investigate all instances where a citizen is injured by police. ${ }^{92}$ Tucker also increased the budget for outside training by 400 percent. ${ }^{93}$

The history of police corruption in Philadelphia can trace its dubious roots back almost to the very beginning of the police department. ${ }^{94}$ Ward leaders exerted their corrupt influence on all the police districts in their areas, and the mayor exercised his corrupting influence over the entire police force. ${ }^{95}$ The police were pawns that the politicians tried to control and use to advance their own interests. With the prevalence of corruption, official probes soon began. The first inquiry into police misconduct was in 1928. A county grand jury claimed that officers were taking as much as two million dollars a year to protect vice. ${ }^{96}$ This grand jury found numerous officers, including detectives, captains, and inspectors, "unfit" to serve.97 Less than nine years later in 1937, another grand jury found that, not only had corruption not been eliminated, but it had actually grown and become more systematic and ingrained. ${ }^{98}$ Vice had flourished between the grand jury investigations. ${ }^{99}$ The grand jury concluded that corruption touched all aspects of the police department. ${ }^{100}$ Corruption functioned in the internal dynamics of the force, extending from promotions to transfers. Corruption was no longer confined to the streets.

Compared with federal prosecutors, whose record of thirty-one convictions in thirty-six federal district court cases between 1983 and 1986 was formidable, local prosecutors had fared less well historically with police corruption cases in the Pennsylvania courts. ${ }^{101}$ In the 1950's, several

88. Hepp, Tucker Casts a New Image for Police, Philadelphia Inquirer, Jan. 5, 1987, at BO1, col. 1.

89. Id.

90. Id.

91. Id

92. Id.

93. Id.

94. Citizens' Crime Commission of Delaware Valley, Vice Enforcement and Corruption in the Philadelphia Police Department 8 (1985).

95. Id.

96. Id.

97. Id. at 9 .

98. Id.

99. Id

100. Id.

101. Heidorn, $A$ Tough Challenge Faces Tucker: Cleaning House, Inside Out, Philadelphia Inquirer, Oct. 21, 1986, at BO6, col. 1 . 
indictments against police were quashed, and seven police officers tried for accepting gambling bribes were acquitted. ${ }^{102}$ In 1971, then Commissioner Joseph O'Neill, Mayor Frank Rizzo, and District Attorney Arlen Spector promoted the need for self-policing and blamed the current cases on the actions of a few rotten apples. ${ }^{103}$ After the Philadelphia Inquirer published a series of articles asserting that the Philadelphia police were accepting payoffs to protect gambling operations, Pennsylvania Governor Milton Shapp ordered an independent investigation of police corruption by the Pennsylvania Crime Commission.104 The Crime Commission report concluded that the history of the Philadelphia Police Department revealed a clear cut trend: Corruption was widespread and continuing, and the department was unable or unwilling to control it. ${ }^{105}$ Although a special prosecutor followed up on the report with the indictment of nine officers, only three were convicted, and the case against the highest ranking senior officer in the group was thrown out of court. ${ }^{106}$ A later study by Watergate Counsel Sam Dash attributed the special prosecutor's problem to the unwillingness of the Philadelphia Police Commissioner to provide the special prosecutor with police records or to suspend officers indicted by his grand jury. ${ }^{107}$

The present investigation of police corruption which began in 1981 has proven to be different than previous investigations. The scope of the investigation has been wider, and convictions with strict sentences have been the rule rather than the exception. ${ }^{108}$ The current investigation of the Philadelphia Police Department began as a result of a complaint filed with the FBI by Donald Hersing, the owner of a house of prostitution. ${ }^{109}$

By far, the predominant police corruption-related activity in Philadelphia has been illegal gambling. Beginning in the late 1970 's, ${ }^{110}$ vending machine companies began buying video poker machines and placing them in bars and taverns in Philadelphia. A patron who played the games would win free games by beating the programmed odds and would be paid off in cash for the free games won, with the bar owner and the vendor splitting equally the profits from the machine. ${ }^{111}$

The illegal gambling use of the machines made the machines subject to seizure and the bar owners or bartenders subject to arrest. The defendants and their coconspirators used the threat of arrest and seizure to extort money from the vendors. At times, a machine was seized or bartender arrested to instigate contact with a vendor and to emphasize the necessity of paying the police for protection. ${ }^{112}$

\footnotetext{
102. Id.

103. Id.

104. Id.

105. Pennsyluania Crime Commission, A Decade of Organized Crime: 1980 Report at x-xi (1980).

106. Heidorn, supra note 101 .

107. Id.

108. Klein, supra note 2, at 114 .

109. Citizens' Crime Commission of Delaware Valley, supra note 94, at 14.

110. Klein, supra note 2, at 108.

111. Id. at 108 .

112. See Government Sentencing Memorandum, supra note 77, at 4 .
} 
This initial investigation of some vice officers led to a city-wide probe-of police taking payoffs to protect vice. ${ }^{113} \mathrm{FBI}$ wiretaps revealed the extent and depth of police corruption in the department. ${ }^{114}$ Vice officers, detectives, a lieutenant, and an inspector all were implicated in this extortion scheme by the FBI wiretaps. In previous investigations, officers were implicated by other officers, but in this investigation, officers implicated themselves on tape recordings.

As the Philadelphia federal prosecutors noted, the government's evidence introduced at the trial of seven officers, including Deputy Commissioner James Martin, established that the defendants used the Philadelphia Police Department to conduct a pattern of racketeering activity, ${ }^{115}$ as defined by the federal RICO statute.116 Martin had been Inspector for the Northwest Division, one of nine in the city, from July 1982 to November 1983. In January 1984, he became Deputy Commissioner of the Philadelphia Police Department. The evidence presented at his trial showed that upon becoming Inspector of the Northwest Division, he received protection money for poker machines and numbers operations from his vice lieutenants, receiving $\$ 10,000$ a month until he was promoted. ${ }^{17}$

In the midst of this secret investigation, newly elected Mayor Wilson Goode appointed a new Police Commissioner, Gregor J. Sambor, Tucker's predecessor. In one of his first major decisions, the new Commissioner consolidated the functions of those officers enforcing vice laws into a new Major Investigations Division. ${ }^{118}$ Until his appointment, vice enforcement operated on tiered levels of responsibility. ${ }^{119}$ Uniformed patrol officers, plainclothes police assigned to district captains and inspectors, and vice officers all enforced vice laws. ${ }^{120}$ The reasoning behind the tiered levels of responsibility was to make the results of payoffs unpredictable as well as expensive. ${ }^{121}$ The costliness and unpredictability of payoffs would force criminals to refuse to pay, and thus the police would enforce the laws.

Sambor made the commander of the Major Investigations Division directly accountable to Deputy Commissioner Martin.122 Martin and his coconspirators planned to use the unit to operate a city-wide, not just

113. Klein, supra note 2, at 111 .

114. Id. at 114 .

115. U.S. v. DePeri, 778 F.2d 963 (3d Cir. 1985).

116. 18 U.S.C. §§ $1961-1968$ (1982).

117. Klein, supra note 2, at 112 .

118. Hepp, Police Chief Shifts Supervision of Ethics Division, Philadelphia Inquirer, Jan. 7, 1987, at BO6, col. 5 .

119. Citizens' Crime Commission of Delaware Valley, supra note 94, at 15.

120. Id. at 15. Police officers testifying at the trials of other officers told how easy it was to take money. One officer described how the tiered level of enforcement was easily circumvented by corrupt police so that they could accept payoffs. This officer said that in order to ensure protection, all he had to do was get in touch with the "cronies in other divisions." Interview with Howard Klein, supra note 78.

121. Citizens' Crime Commission of Delaware Valley, supra note 94, at 16.

122. Id. 
division-wide or precinct-wide, extortion ring. ${ }^{123}$ All vice operations would pay the officers in their district, and the officers would then give Martin a percentage of the money. ${ }^{124}$ Before Martin could put his plan fully into motion, the FBI identified most of the conspirators, and the grand jury started to hand down indictments. ${ }^{125}$ Thirty-one police officers and officials, including Deputy Commissioner Martin, were convicted. ${ }^{126}$ The significance of the trials was not the news of police corruption. The news was that not just lower ranking officers were indicted. ${ }^{127}$ Four lieutenants, a captain, an inspector, a Chief Inspector, and the Deputy Commissioner all were charged with various crimes. ${ }^{128}$ The convictions of these men and the other officers destroyed the "bad apple" explanation. ${ }^{129}$ Corruption was shown to be farreaching and associated with all ranks.

In addition to the Philadelphia Task Force, the Citizens' Crime Commission of Delaware Valley has also made several conclusions and recommendations for the Philadelphia Police Department. ${ }^{130}$ One conclusion they draw is that the higher ranks must be intolerant of corruption. ${ }^{131}$ Tucker's tenure has been a welcome event in this regard. The Commission also suggests that the "rotten apple" theory of corruption has been abandoned, to the extent that the theory only reinforces the code of silence and acts against systematic reform of the police department. ${ }^{132}$

The Philadelphia Police Department has implemented some of the recommendations: requirements of full financial disclosure for all candidates for command level promotions; limited tenure in specialized vice and narcotics units; prosecution of all involved in corruption including officers, officials, and citizens; lenient treatment of officers cooperating with official investigations in regard to their own misconduct; arousal of public concern; establishment of field associates; and, finally, establishment of proactive instead of reactive probes of possible corruption. ${ }^{133}$ The department is working on implementing two other recommendations. ${ }^{134}$ The first recommendation is the establishment of a system to reward technical specialization independent of the promotion process. ${ }^{135}$ Often excellence in

123. Id. at 17 .

124. Id.

125. See Interview with Howard Klein, supra note 78.

126. Lounsberry, Crime Fighter Regretfully Says Goodbye, Philadelphia Inquirer, Jan. 17, 1987, at BO1, col. 1 .

127. Klein, supra note 2, at $111,112$.

128. Id. at 114 .

129. Citizens' Crime Commission of Delaware Valley, supra note 94, at 18.

130. Id. at 23-32.

131. Id. at 23. Interview with Ian Lennox, Executive Director, Citizens' Crime Commission of Delaware Valley in Philadelphia (Mar. 19, 1987).

132. Citizens' Crime Commission of Delaware Valley, supra note 94, at 18 .

133. Interview by Angelo Duplantier, University of California-Irvine student, with lan Lennox, Executive Director, Citizens' Crime Commission of Delaware Valley (Jan. 21, 1987); Angelo Duplantier, Too Much Brotherly Love in the Philadelphia Police Department (unpublished student paper, Mar. 20, 1987) (Program in Social Ecology, University of California, Irvine).

134. Id.

135. Citizens' Crime Commission of Delaware Valley, supra note 97, at 23. 
a particular field is rewarded by promotion. Many times these promotions remove the officer from precisely the area where his or her expertise lies. The second recommendation that is likely to be implemented is a plan to distribute vice intelligence so that the Major Investigations Division, Ethics Accountability Division, and/or Internal Affairs Division are all apprised of the investigation. ${ }^{136}$ Monitoring of vice operations is critical in reducing police corruption. When officers know they are being watched, they are less likely to misbehave.

The many recommendations of the Philadelphia Police Study Task Force, which include drug testing, the institution of mechanisms to transform police managers from narrow supervisors to more effective decisionmakers, "civilianization," more community policing techniques, and enhanced training, all are directed at institutional reforms which will make the police more responsible for controlling and preventing corruption. ${ }^{137}$

The efficacy (or lack thereof) of prosecution as a deterrence strategy was highlighted by the argument of Philadelphia law enforcement officials who indicated that real reform depended less on the prosecutions than on the organizational changes Tucker had introduced and the commitment of his eventual successors to maintain them. ${ }^{138}$ If political ties among city hall, the police, the district attorney's office, and the courts reasserted themselves, less aggressive prosecution of police might result. ${ }^{139}$

The ability of the Philadelphia Police Department to institutionalize anticorruption sentiment and control capabilities will be tested after the initial vigilance of the Tucker administration dies down. Whether this city, with its checkered history of police malfeasance, will adopt new approaches will be a major national test of the efficacy of police reform.

IV

\section{New York CitT}

With over 27,000 officers, New York City by far enjoys the largest police department in the country, ${ }^{140}$ charged with the protection of a diverse population of over seven million. ${ }^{141}$ The task of policing New York City has long been a demanding one, and the history of police corruption in New York City has long roots, including periodic assessments of desired corruption control mechanism. The early 1970's saw the revelations of Detective Frank Serpico, ${ }^{142}$ the study by the Knapp Commission, ${ }^{143}$ and the corruption

\footnotetext{
136. Id. at 28.

137. Philadelphia Police Study Task Force, supra note 79, at 153-63.

138. Interview with Gerald M. Caplan, Professor of Law, George Washington University Law School (Mar. 17, 1987).

139. Interview with Howard Klein, supra note 78.

140. 1988 Information Please Almanac 798 (4lst ed. 1988).

141. Id. at 761 .

142. P. MaAs, Serpico (1973).

143. See Knapp Commission Report, supra note 29.
} 
episodes of the elite Special Investigation Unit detailed in The Prince of the City. ${ }^{144}$

With the exposure of some crack-related corruption events in the mid1980 's, ${ }^{145}$ New York City was once again thrust into the spotlight, amid acrimonious disputes between rank and file officers and the police commissioner. The recent New York City police corruption problems took place against the largest increase in serious crimes ( 5 percent) in five years, including a 14 percent increase in murder from 1985 to $1986 .{ }^{146}$ In the revelations to date, including trial testimony by one officer against another, ${ }^{147}$ allegations of entrapment, ${ }^{148}$ and the suicide of one implicated officer, ${ }^{149}$ evidence indicates that New York Police Department (NYPD) officers in a remote precinct regularly stole or accepted drugs and money from marijuana and crack dealers. ${ }^{150}$ After having been disciplined for a departmental infraction, one implicated officer had been transferred to the "dead end" precinct from the narcotics division a few years prior, thus exposing the limitations of internal disciplinary action against police officers. ${ }^{151}$

When New York Police Commissioner Benjamin Ward responded to the scandal by ordering a rotation plan including 20 percent of all officers, the Police Benevolent Association countered with a work slowdown among other means and caused Ward to rescind the action. ${ }^{152}$ The largest percentage of official complaints regarding police behavior received by the NYPD in 1985 (22 percent) concerned narcotics. ${ }^{153}$ The 644 narcotics-related complaints were 36 percent more than in 1984.154 "Two-thirds of the increase in narcotics complaints between 1984 and 1985 involved allegations of drug use by members of the service and alleged protection of drug dealers."155 In 1985, New York officers with less than five years of experience constituted 45 percent of the police force but were responsible for 89 percent of the drug charges and 72 percent of the complaints received by the Civilian Complaint Review Board (CCRB). ${ }^{156}$ Such overrepresentation, however, could be explained by the fact that younger officers comprise 75 percent of the street patrol force or that newer police officers are more frequently assigned to front-line operations, such as lower Manhattan's "Operation Pressure

144. R. Daley, Prince of the City 25-27 (1978).

145. Purdum, 12 from Brooklyn Precinct Arraigned on Broad Range of Charges, N.Y. Times, Nov. 7 , 1986 , at 15 , col. 2 .

146. Purdum, Serious Crimes in New York City Rise 5\%, First Increase in 5 years, N.Y. Times, Mar. 20, 1987, at Al, col. 1 .

147. Buder, Officer Tells Why He Decided to Inform on Others, N.Y. Times, May 7, 1987, at B8, col. 4.

148. Shipp, An Inquiry or a Trap?, N.Y. Times, Sept. 27, 1986, at 12, col. 1.

149. Purdum, Missing Indicted Officer Found Dead in Motel, N.Y. Times, Nov. 8, 1986, at 1, col. 2.

150. M. MCAlaRY, Buddy Boys, supra note 4.

151. Officer in Graft Trial Called Naive by Lawyer, N.Y. Times, Apr. 28, 1987, at A29, col. 3.

152. Purdum, Ward Says Slowdown by Officers Has Worsened and May be Illegal, N.Y. Times, Nov. 13, 1986, at $\mathrm{Al}$, col. 3.

153. 2 New York City Mayor's Advisory Committee on Police Management and Personnel

Policy 171 (1987) [hereinafter Mayor's Advisory RePORT].

154. Id.

155. Id.

156. Id. at 23 . 
Point."157 Moreover, city police officers called drug use their primany corruption problem in 1986.158 For the first time, the NYPD's annual corruption assessment survey ${ }^{159}$ found growing concern among commanders over the possibility of drug abuse by off-duty officers. Even the many advances made by the NYPD as far as instituting mechanisms for corruption control were being questioned. ${ }^{160}$ More recent probes found that management controls within the NYPD were inadequate for the early identification and disposition of those individuals with a propensity toward misconduct. ${ }^{161}$

The police scandals paled alongside three major upperworld and underworld crime prosecutions in the mid-1980's. The highest levels of the borough party machinery were prosecuted for municipal corruption, including payoffs in the city's parking violations bureau. ${ }^{162}$ At the same time, another unit of the federal prosecutor's office was focusing on insider trading schemes on Wall Street, resulting in a flurry of criminal prosecutions and fines. ${ }^{163}$ By no means the least of the three scandals was the trial of leaders of the five New York organized crime families in the celebrated "Commission case." 164

The Knapp Commission was created in the early 1970's by then Mayor John Lindsay, as a result of the publicity generated by renegade detective Frank Serpico. ${ }^{165}$ After failing to get any support or action from his superiors in the department, Serpico went to the New York Times with a story outlining police corruption. ${ }^{166}$ The resulting publicity forced Lindsay to appoint Whitman Knapp, a Wall Street attorney, to head an independent commission to look into the matter. ${ }^{167}$ After months of hearings, investigation, and deliberation, the commission found institutionalized, widespread corruption in the NYPD. ${ }^{168}$ They further determined that there was organized protection of vice by the NYPD. ${ }^{169}$ In fact, according to the report, the climate of the department is inhospitable to attempts to uncover acts of corruption, and protective of those who are corrupt. ${ }^{170}$

157. Id. at 24.

158. Id.

159. Kerr, Officers Facing Drug Charges Call 11 Others Cocaine Users, N.Y. Times, Mar. 19, 1986, at B1, col. 4 .

160. Purdum, Suspensions Stir Accountability Issue, N.Y. Times, Sept. 24, 1986, at B4, col. 4.

161. I MAYOR's Advisory REPORT, supra note 153, at 7.

162. Sheron, U.S. Officials See Historic Effort to Combat Municipal Corruption, N.Y. Times, Mar. 30 , 1986 , at 1 , col. 1 .

163. Kilborn, U.S. Said to Issue Subpoenas Linked to Boesky Trading, N.Y. Times, Nov. 17, 1986, at 1, col. 1 .

164. Lubasch, Mob's Ruling 'Commission' to Go on Trial in New York, N.Y. Times, Sept. 7, 1986, at 51, col. 1 .

165. See Knapp Commission Report, supra note 29.

166. P. MAAs, supra note 142 .

167. KnApP Commission Report, supra note 29.

168. Id. at 1 .

169. Id. at 2 .

170. Id. at 5-7. 
“-The Knapp Commission recommended that commanders must be held accountable for their subordinates' actions, that commanders were to prepare periodic reports on the key sites and situations that could breed corruption, and that field officers of the internal affairs division were to be created at all precincts, and were to be staffed by undercover informants in each precinct. ${ }^{171}$ The police department in New York responded to the Knapp-era scandal by taking several courses of action: decentralizing authority and responsibility, reducing the autonomy of the detective branch, setting new standards of accountability for senior officers, instigating proactive investigatory procedures for police deviance, altering certain aspects of enforcement, rotating personnel, and emphasizing integrity in training. ${ }^{172}$

With those ideas in mind, Commissioner Patrick Murphy was appointed to clean up the department. Murphy was a no-nonsense ex-NYPD officer who was passionate in his hatred of corruption. ${ }^{173}$ Murphy used the Knapp findings as a battle cry to revamp the department completely. "There were massive transfers of senior officers, rotation of policemen in sensitive areas, and ... [a severe reduction of] the autonomy of the detective branch."174 A new policy of accountability and decentralization was instituted. Murphy told 180 commanders that he would hold each of them personally responsible for any misconduct within the ranks at any level of command. ${ }^{175}$ Murphy revamped the internal investigatory system, which up to that point seemed "deliberately designed not to work," 176 by sponsoring proactive internal affairs projects with "integrity tests on field associates." 177 Unit commanders were unaware of the identity of those field associates. ${ }^{178}$ Murphy also attempted to alter the "opportunity structure" for corruption by "virtually ending enforcement of gambling and Sabbath laws, by providing policemen with sufficient funds to pay informants, and by starting a campaign to arrest those citizens offering bribes." 179 By using political, legal, and press support, Murphy was successful in reducing the corruption problem to a very "minimal level." 180 Murphy's biggest contribution, however, possibly was his development and deployment of those proactive means for the prevention of corruption. Those programs marked a change in the focus of anti-corruption efforts. Murphy tried to avoid corruption before it started, rather than waiting for it to become a problem again. His success was commendable. In a number of informal police interviews by the criminologist, Maurice Punch,

171. Id. at 16-34.

172. See M. Punch, supra note 21, at 27-28; see also B. Gelb, Varnished Brass: The Decade AFTER SERPICO (1983).

173. See P. Murphy \& T. Plate, Commissioner 167 (1977).

174. M. РUNCH, supra note 21, at 27.

175. P. Murphy \& T. Plate, supra note 173, at 239.

176. Id. at 217-54.

177. Id. at 237.

178. Id.

179. M. Punch, supra note 21, at 28; see also John F. Kennedy SChool of Government, Harvard University, The Knapp Commission and Patrick Murphy 182 (1977).

180. M. PUNCH, supra note 21, at 28. 
conducted in 1980 and 1981, members of the NYPD spoke of the "revolution" put into place by Murphy. ${ }^{181}$ In his 1978 book, Scandal and Reform, criminologist Lawrence Sherman wrote, "from all indicators the most recent episode of scandal and reform in the NYPD has reduced police corruption to a very minimal level."182 Four years later the New York Times stated that " $[t]$ he whole climate of the department has been reversed since Knapp." 183

As early as 1973, however, just one year after the Knapp Commission released its findings, a corruption profile conducted by the Intelligence Section of the Internal Affairs Department found that while some traditional forms of graft had diminished, other forms of corruption (such as theft from suspects and impounded cars, and the use of prostitute services under the threat of arrest) were on the increase in certain precincts. ${ }^{184}$ Despite the gains made by Commissioner Murphy, corruption in the NYPD was far from over.

In the years immediately after Knapp, lapses of resurgent corruptive practices occurred in the NYPD. In addition to the Special Investigative Division "Prince of the City" Scandal,185 in 1981, 1983, and 1985, small episodes of localized corruption (some related to bribes from club owners) took place in selected precincts. ${ }^{186}$

In 1986, however, a major scandal in a Brooklyn precinct erupted which embraced the police commissioner, the Police Benevolent Association (PBA), and the Major's Office. Thirteen officers from the 77th Precinct in the Bedford-Stuyvesant area were indicted on various charges including stealing and selling drugs. ${ }^{187}$ The group of officers included some who had been transferred to the 77 th Precinct because they were disciplinary problems at other locales. Some were eighteen-year veterans of the NYPD. ${ }^{188}$ The major source of temptation was from drug dealers, their cash revenues, and even their illicit substances. ${ }^{189}$ The officers who were involved in the activities offered many rationalizations for their acts: they were harassing drug dealers and the criminal justice system would not do anything anyway; they were robbing criminals or "lowlife," they were not law-abiding citizens; and they were displacing crime from their precinct. ${ }^{190}$

Some observers found a reassuring aspect in the 77 th Precinct scandal: Through the use of the Internal Affairs Department, the city police responded

181. Id.

182. L. Sherman, supra note 21 , at xxix.

183. Farber, Decade After Knapp Inquiry, A Sense of Revolution Pervades Police Force, N.Y. Times, Nov. 29,1982 , at B1, col. 1. "But as a widespread and organized thing, as something that was once accepted, that's gone. The whole climate of the department has been reversed since Knapp." Id.

184. M. Punch, supra note 21 , at 28.

185. See R. DaleY, supra note 144.

186. Police Corruption: A Look at History, N.Y. Times, Sept. 24, 1986, at 84, col. 5.

187. Purdum, 12 from Brooklyn Precinct Arraigned on Broad Range of Charges, N.Y. Times, Nov. 7, 1986, at 15 , col. 2 .

188. Purdum, Officer Admits Guilt in Sale of Cocaine, N.Y. Times, Mar. 11, 1987, at B1, col. 6.

189. M. MCAlarY, supra note 4; Drug Influx a Strain on the Best, N.Y. Times, Sept. 2, 196, at BI, col. 1 .

190. M. MCALARY, supra note 4 , at 171 . 
well to the investigation of the charges of corruption. ${ }^{191}$ One immediate response from the Police Commissioner was frequent reassignment of patrol officers to prevent entrenchment of corruptive practices and influences. ${ }^{192}$ In response, the PBA encouraged work slowdown which demonstrated the rank and file's resistance to the Commissioner's plan. ${ }^{193}$ The slowdown caused the Commissioner to delay his plan. ${ }^{194}$ Some hoped the scandal would direct police attention to itself and would result in better policing and better police/community relations. ${ }^{195}$

According to the 1987 Zucotti Report, ${ }^{196}$ New York was also suffering from a severe supervisory crisis. This crisis was caused by several factors: "long-term vacancies for the position of sergeant, the inexperience of many new supervisors, the absence of an effective system of performance evaluation, inadequate training and the distinct supervisory needs of a young police force." 197 The report concluded:

The net result has been a tendency to move authority and responsibility upward within the ranks, thereby diminishing the stature of the sergeant as a key actor at the first line of supervision. A companion result is that less responsibility and accountability is delegated to those whose like supervision is essential for the prevention of misconduct. ${ }^{198}$

Furthermore, the panel found that the NYPD lacked an effective program of field in-service to reinforce what was initially learned at the Academy. ${ }^{199}$

As what may be the most studied American police department, the NYPD's recent corruption episodes echo the concern that illegal drug use and sales in the 1980's pose new and more serious temptations for corruption. Corruption issues will remain a salient topic of contention in the more general discussion of management relations and policing strategies.

\section{Boston}

Boston, like the other four cities described at length in this article, is not a stranger to municipal corruption. Professor Herman Goldstein, responding to reports of a recent Boston police scandal, noted that " '[c]orruption has

191. The Cops Caught the Crooked Cops, N.Y. Times, Sept. 26, 1986, at A34, col. 1 (editorial). One of the more controversial issues involved in the 77th Precinct scandal was the use of some police officers to wear recording devices, or "wires" on their bodies, or otherwise provide testimony against their fellow officers, thus piercing the traditional "blue wall" of police silence and solidarity amid investigation of corruption charges. See M. MCAlary, supra note 4, at 230-51; see also Purdum, supra note 187 .

192. Boorstin, Ward, Defending Transfers, Calls Some Officers "Bandits," N.Y. Times, Nov. 10, 1986, at B1, col. 2. 3.

193. Purdum, Anti-corruption Moves Set Off Slowdown by Police, N.Y. Times, Nov. 11, 1986, at 14, col.

194. Purdum, Ward Agrees to Delay His Precinct Transfer Plan, N.Y. Times, Nov. 14, 1986, at 1, col. 1.

195. Smothers, In Drug-Wracked 77th Precinct, Police Suspensions Draw Varied Reactions, N.Y. Times, Sept. 25, 1986, at B4, col. 1 .

196. 2 MAYOR's ADVISORY REPORT, supra note 153, at 7.

197. Id.

198. Id. at $7-8$.

199. Id. at 84 . 
been part of the culture in Boston for a long time. . . It's more accurate to view these things as the ebb and flow of officialdom's willingness' to investigate corruption." 200 In recent years, however, the trial of Boston mob boss, Geraldo Angiullo, brought the issue to public attention. During the trial, willful police blindness to illegal gambling and loansharking operations associated with Angiullo's organization was uncovered. ${ }^{201}$ The scandal was the most serious since 1976, when the Special Investigations Unit charged that the Department was rife with corruption and incompetence. ${ }^{202}$

In Boston, one complication when dealing with police corruption is that Boston police officers are official agents of the Boston Licensing Board and possess power to inspect bars for compliance with liquor regulations. ${ }^{203}$ Thus, another key element in the Angiullo scandal was the existence of offduty police detail programs which permitted police officers to work afterhours in privately owned businesses, including such licensable facilities as bars or restaurants. ${ }^{204}$ After a noted shakedown episode caused publicity in the mid-1970's, ${ }^{205}$ Police Commissioner Robert J. diGrazia prohibited the offduty details, but they slowly reemerged through restaurants and grocery stores. ${ }^{206}$ Still, some changes have been made to limit the temptation for informal or illegal agreements. While the Boston Police Department does not keep track of which police officers work off-duty details or how often they do so, the officers are at least now paid by check instead of by cash, as was the case in the past. ${ }^{207}$ Accusations of harassment and vigilante activity by members of the Boston Police Department were made. ${ }^{208}$

In Boston, three theories of the origins of the recent complaints regarding police corruption have emerged. One maintains that the owner of a gay bar took the tale of police shakedowns to the FBI after he grew tired of paying off police officers. ${ }^{209}$ Another version has the FBI, working from similar information, using implicated police officers to collect evidence by placing body wires on them to record conversations with confederates. ${ }^{210} \mathrm{~A}$ third version holds that a rising number of complaints led ranking Boston police officers to engage in greater departmental investigation efforts. ${ }^{211}$

200. Larmer, Indictments Rock Bay State Police, The Christian Science Monitor, Aug. 1, 1986, at 3, col. 4.

201. Merry, Simmering Boston Police-Corruption Changes Boil Over Again, The Christian Science Monitor, Oct. 27, 1986, at 5, col. 1.

202. Birtwell, Another Shot at Hub Police, Boston Herald, Oct. 23, 1986, at 7, col. 1 .

203. Alters \& Paz-Martinez, Charges Leveled of Illegal Payoffs to Boston Police, Boston Globe, Dec. 21 , 1986, at 33, col. 1 .

204. Id.

205. Id.

206. Id.

207. Id.

208. Birtwell, supra note 202.

209. Paz-Martinez, Many Theories on Cause for Payoff Probe, Boston Globe, Dec. 21, 1986, at 53, col. 1 .

210. Id.

211. Id. 
In October 1986, a pair of top-ranking federal officials appeared with Police Commissioner Francis M. Roache to announce that a grand jury was hearing evidence about allegations of widespread corruption in the Boston Police Department. ${ }^{212}$ The investigation, which had been going on for five years, focused on patterns of corruption involving top administrators, not just rank and file officers. ${ }^{213}$

Certain district stations were targeted as centers of police misconduct, in particular involving protecting criminal activities at bars and other licensed premises in return for cash and favors. ${ }^{214}$ The General Investigations Units and the district stations of Dorchester, Roxbury, West Roxbury, and Downtown began to be investigated. ${ }^{215}$ Investigators were trying to determine if officers on paid details at private clubs took payoffs and intercepted violation reports so that no punitive action was taken against the license holder.

Records on personnel, paid detail assignments, licensed premise inspections, and incident reports of criminal violations at licensed premises, some dating back ten years, were seized from the four district stations. ${ }^{216}$ The grand jury also subpoenaed voluminous records at two city hall agencies that oversee liquor and entertainment licenses. ${ }^{217}$ Records of the Mayor's office of Consumer and Licensing Affairs, which regulates entertainment permits for such things as peepshows, jukeboxes, and video games, were subpoenaed as well. 218

Boston Police Commissioner Roache and Mayor Flynn have been cooperating with the investigation fully. Flynn said, "They made it very clear to me that very serious problems with corruption existed in the Boston Police Department. We have participated fully in an intensive investigation. You will begin to see the results in the coming weeks and months." 219 Roache pledged his full support to the investigation after being told of its purpose, "regardless of wherever and to whomever the investigation may lead."220 Former Commissioner Joseph Jordan (Commissioner, 1976-1985), however, was never told about the investigation even though the probe was underway during his time in office. ${ }^{221}$ Jordan was indirectly linked to the alleged payment of bribes to more than fifty city officers for overlooking under-thecounter sales of illegal drugs. ${ }^{222}$ Jordan denied the accusation. 6.

212. Cullen \& Connoily, Records Seized in Probe of Hub Police, Boston Globe, Oct. 23, 1986, at 1, col.

213. Id.

214. Fehrnstrom, Murphy \& Mooney, Massive Fed Probe of Police, Boston Herald, Oct. 23, 1986, at 1 , col. 2.

215. Id.

216. Id.

217. Id.

218. Id.

219. Id.

220. Id.

221. Id.

222. Cullen \& Connolly, supra note 212. 
Instances of police corruption uncovered in Boston involve many illegal activities. Charges of illegal shakedowns, bribes, drug trading, vice operations, and harassment have cast the greatest blow to the morale and reputation of the Boston Police Department. For example, in the fall of 1986, convicted copshooter and drug dealer Jesse Waters became a federal witness in exchange for protection by federal prosecutors. ${ }^{223}$ Another recent string of allegations involved Boston police officers taking bribes for overlooking violations of liquor license laws at bars. ${ }^{224}$ Several bar owners describe situations where officers threatened to cite bar owners for liquor license violations if they did not pay off the officer. ${ }^{225}$

One bar owner explained, "[s]imply put, if you owned a bar in Boston, sooner or later you paid someone for protection."226 Special circumstances would exacerbate this arrangement. If someone was caught with drugs on the bar's premises, the threat to a bar's license could be significant. The most vulnerable bars were gay bars. ${ }^{227}$ One former club owner informed the Boston Globe that he did not believe that gay establishments were approached because they might violate the laws, but because owners of gay clubs are forced to pay just to stay in operation. ${ }^{228}$ Rumors even maintained that some liquor licenses in the city were owned by city police. ${ }^{229}$ Eventually, seven Boston police officers were indicted under the RICO statute for obtaining kickbacks from Boston restaurants and nightclubs. ${ }^{230}$

\section{VI}

\section{San Francisco}

The city of San Francisco has weathered decades of political conflict resulting from the diversity of the city's population, no more so than in recent years when Bohemians, hippies, commune members, activist groups, gay and lesbian communities, and various influxes of immigrants have made San

223. Waters was the star witness in the case against Boston Police detective George Vest, who was convicted on two counts of perjury when he denied receiving cash from Waters in return for allowing Waters to sell marijuana over-the-counter at his Roxbury variety store. Vest was convicted of lying to a federal grand jury. In the second count, Vest was convicted of lying when he denied acting as the middleman in a bribery scheme to fix a court case. Waters testified he paid bribes to more than 50 police officers, including former Commissioner Jordan, to protect his drug dealing business. All those named by Waters denied receiving any payoffs. Vest testified that he paid $10 \%$ of his $\$ 18,000$ a-week income from his stores to police officers in bribes for protection. He said he gave the money out in brown paper bags. Besides protection, Waters said police provided him with advance information about raids and told him when his store would be under surveillance. Doherty, supra note 5 .

224. Criminal Indictment in U.S. v. Boylan, No. A.87-345 (D. Mass. Nov. 9, 1987); 7 Indicted in Case on Boston Police, N.Y. Times, Nov. 11, 1987, at A28, col. 4.

225. Cullen \& Malone, Kickback Probe is Widespread, Boston Globe, Oct. 24, 1986, at 1, col. 6.

226. Paz-Martinez, Ex-bar Owner: Police Solicited $\$ 500$ “Tip," Boston Globe, Dec. 21, 1986, at 54, col. 4 .

227. Alters \& Paz-Martinez, supra note 203.

228. Id.

229. Paz-Martinez, 700-900 Hub Liquor Citations Issued Yearly, Boston Globe, Dec. 21, 1986, at 53, col. 1 .

230. See Indictment, supra note 224. 
Francisco a unique melting pot. The drug culture of the 1960's and the gambling dens of Chinatown have grown along with the prostitution in the hotel district in this most Eastern of West Coast cities. Since police are conservative and dominated by an Irish-American tradition, they have been thrown into even more conflict with the diverse lifestyles and groups. The 1978 assassination of a liberal mayor and gay city/county supervisor showed the cleavages, some vice-related, existing below the cheerful facade of a popular tourist destination. ${ }^{231}$

After a police recruit graduation dinner in 1985, a bashful recruit was handcuffed to a chair, where a prostitute was brought in to perform oral sex on him. ${ }^{232}$ Of the many officers present, several of whom were recruits, not one person reported the Rathskellar incident. ${ }^{233}$ The internal investigation of that incident was hampered by the traditional code of silence. Chief Cornelius Murphy recommended harsh penalties for all of the officers involved and circulated a code of ethics paper. ${ }^{234}$ Eventually, he recommended the firing of two recruits, two veterans, and two sergeants. ${ }^{235}$ As a result of that incident and a series of others, ten of twenty-one captains were reassigned to new divisions. ${ }^{236}$

The number of reports of police brutality had increased, ${ }^{237}$ and three San Francisco police officers were tried and cleared of charges that they kidnapped and beat a local Chinese gang member. ${ }^{238}$ The rate of complaints exceeded that of the more drug-plagued city of Oakland and the much larger city of Los Angeles, prompting concern by Mayor Dianne Feinstein. ${ }^{239}$ In response to the mayor's questioning, the deputy police chief claimed that the difference reflected the different reporting methods among cities and San Francisco's willingness to process complaints. ${ }^{240} \mathrm{He}$ also pointed to the job maturity issue, noting that, as in New York, 50 percent of San Francisco's officers had less than five years experience. ${ }^{241}$ Chief Murphy pointed to the youthfulness of the police force, noting that they lacked discipline and military experience. ${ }^{242}$

231. W. Hinckle, Gayslayer (1985); F. Fitzgerald, Cities on a Hill: A Journey Through Contemporary American Cultures (1986).

232. Chung \& Magagnini, Sex Probe Must Allow Legal Counsel for Cops, San Francisco Chron., May 5, 1984 , at 1 , col. 2 .

233. Hughes, Chief Orders Ethics Talks for Police, San Francisco Sunday Examiner and Chron., June 10,1984 , at 1 , col. 2.

234. Id.

235. Chung \& Leary, Murphy Livid, San Francisco Chron., May 3, 1984, at 1, col. 4.

236. Officers Reassigned in Coast Police Scandal, N.Y. Times, Sept. 9, 1984, at 31, col. 1.

237. Wallace, Big Rise in Complaints Against Police in S.F., San Francisco Chron., May 25, 1984, at 1, col. 6.

238. San Francisco Chron., July 24, 1984, at 4, col. 1 .

239. Wallace, Feinstein Calls for Meeting on Police Dept., San Francisco Chron., May 25, 1984, at 1, col. 1 .

240. Id.

241. Id.

242. Wallace, supra note 237. 
While the officers were technically better than their predecessors, Murphy noted that they lacked street sense. ${ }^{243}$ Murphy developed a two-tiered system of intervention to deal with corruption which included the addition of situational ethics problem-solving courses in the academy curriculum and participation by officers in peer group sessions on ethics. ${ }^{244}$ Departmentwide, day-to-day accountability and a drive to strengthen the chain of command within the department were introduced. ${ }^{245}$

A San Francisco Police spokesman has explained that the San Francisco system, in which nine district stations cover the city/county, has been the basis for a form of team policing, though it is not pure team policing. ${ }^{246}$ Every police officer has a personnel evaluation program folder, which is retained at the workplace and maintained by a sergeant in charge. ${ }^{247}$ Weekly reviews of each officer are held, and praise, as well as counsel, is used to indicate the department's evaluation of the officer. According to the San Francisco Police Department (SFPD), this has been a very promising intervention. ${ }^{248}$ In effect, the system provides immediate supervisors for everyone, at low expense. All new sergeants are instructed in the supervisory system, and over time existing sergeants will be instructed. Two changes have been made in the police academy and training routines. ${ }^{249}$ At the academy, a two-hour class on ethics and professionalism is taught in the first week. San Francisco has gone beyond the state standards dictated by the Police Officers Standards Training (POST) system and mandated more hours of ongoing education and training. SFPD has sought to provide an example by sanctioning officers at the top of the system, as well as at lower levels. ${ }^{250}$ The city has enhanced its field training officer system, in the belief that more officers learn from the peer group level than from teachers. ${ }^{251}$ One police lieutenant, however, indicated that the problems evidenced by the Rathskellar recruit incident would not be cured by these measures and mandated a different supervisory posture. ${ }^{252}$

On another front of the vice effort, the gay-bashing issue has led to several changes in the way in which the Department approaches that visible and politically active minority community. ${ }^{253}$ At various stations, ongoing community relations have been furthered by police bringing in local gay and lesbian community leaders for "gripe sessions," which have been very valuable in reducing the distance between the police and the policed.254 At the same time, the community relations department employs an openly gay

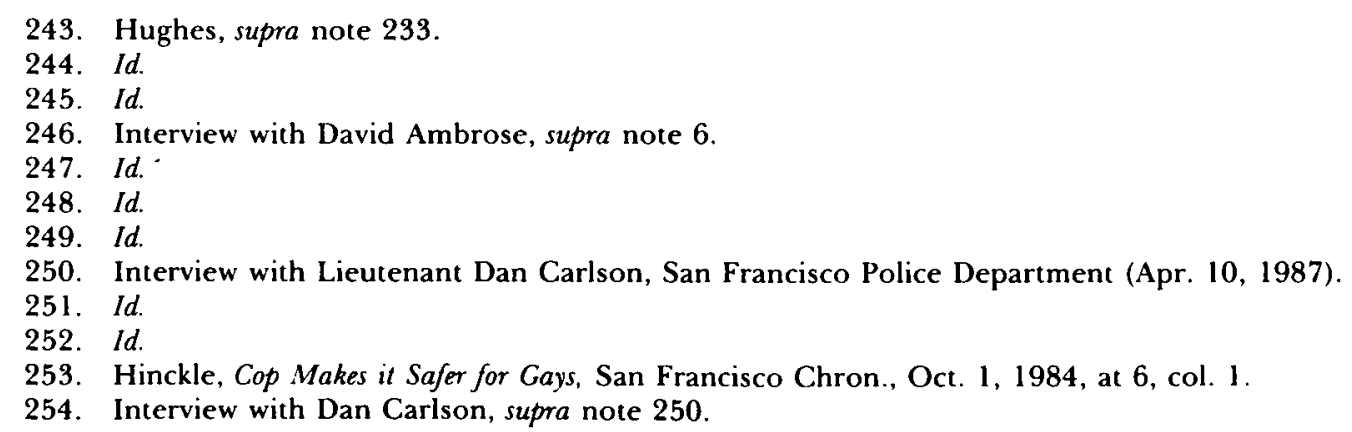


officer as a liaison to the gay and lesbian community. At the Police Academy, sensitivity training has been introduced. One week is spent discussing the minority communities in the city. One day is scheduled each for blacks, Asians, and gays, a seemingly brief time but an improvement over prior efforts. While some problems are encountered when policing the rougher gay bars in the city, the police department has made strides since the riots caused by the relatively light sentence that was handed to former supervisor and police officer Dan White, the killer of the liberal mayor and gay supervisor. ${ }^{255}$

\section{VII}

\section{Conclusion}

For many years, criminologists have identified a host of factors which generate or maintain corruption, as well as defining possible bases for legal and institutional mechanisms to prevent, discover, or punish such corruption. ${ }^{256}$ Changes in American approaches to vice in the last decade have altered the parameters of police corruption control.

For instance, Goldstein observed, "Corruption thrives best in poorly run organizations where lines of authority are vague and supervision is minimal."257 Kornblum identified several obstacles to compliance which included lack of knowledge of how to change existing attitudes, insufficient time to do so, competing external incentives, and conflicting organizational goals. ${ }^{258}$ To Sherman, three elements of internal administration are important in controlling corruption: increased internal accountability as led by an active and committed chief, the strengthening of front-line supervision over both the work time and work products of subordinates, and the implementation of a program of positive discipline which rewards integrity and abolishes those formal procedures which inadvertently encourage corruption. ${ }^{259}$ While informal procedures such as interdepartmental transfers are used more often than formal procedures, Punch explains that internal disciplinary procedures are slow, cumbersome, inadequately staffed, and are "hindered by the perceived illegitimacy of a vast array of petty and out-of-date discipline regulations." 260

Whereas anti-corruption measures must be realistic, manageable, and continually reinforced to be successful, the importance of civilian review is questionable. ${ }^{261}$ Experience in several cities indicates that civilian review is less likely than police internal review to find officers guilty of misconduct and is more lenient in its disciplinary recommendations when it does find officers

255. Id.

256. See generally L. Sherman, supra note 21; M. Punch, supra note 21 .

257. H. Goldstein, Policing a Free Society 210 (1977).

258. A. Kornblum, supra note 21 , at 5.

259. L. ShERMAN, supra note 21 , at 120-34.

260. M. PUNCH, supra note 21 , at 198.

261. 2 MAYOR's AdVISORY RePORT, supra note 153. 
guilty. ${ }^{262}$ Others argue that in instances where police themselves gather, assemble, present, interpret, and then judge the facts related to misconduct complaints, few serious complaints are likely to be sustained. ${ }^{263}$ In contrast, Goldstein points out that no civilian board can exert the kinds of immediate and day-to-day influences on officers' street performance that are traditionally the responsibilities of the chief. ${ }^{264}$ In fact, close supervision seems to have a negative, rather than a positive, effect on policing. ${ }^{265}$ Increasing the number of supervisors relative to patrol officers, without making other changes, may be very costly and of little significance.

Consequently, police organizations which wish to reduce incidents of corruption in the face of a constant level of vice face several dilemmas. First, a longstanding debate exists between those who advocate further decriminalization of vice, even legalization in some instances, ${ }^{266}$ and others who believe that the disorder caused by tolerance of vice can lead to the furthering of more serious crime. ${ }^{267}$ Second, the issue of centralizing vice patrol responsibility as opposed to decentralizing it continues to cause debate, and proponents of either side can cite information supporting the reasonableness of embracing either approach. ${ }^{268}$ Similarly, a third issue, which might be termed a specialist versus generalist debate, parallels a disagreement on that theme regarding policing as a whole. ${ }^{269}$ Namely, are police who specialize in vice control more effective or efficient, independent of their corruptability, than police who encounter vice as one item in the course of their enforcement duties? The fourth issue is the conflict between autonomy and supervision. ${ }^{270}$ This is particularly meaningful when the topic of community policing arises and beat integrity conflicts with the rotation of police personnel to prevent entrenchment of corruption.

The problems of drug use and drug-related police corruption have grown since the time when the Knapp Commission could identify drug-related corruption as "dirty" graft. ${ }^{271}$ The crack phenomenon, however shortlived or exaggerated, has brought police in certain cities into more contact with street sales of cocaine, at the same time as cocaine use has spread throughout middle-class society. New York police officials now identify use of drugs by police as their foremost corruption problem rather than other misconduct

262. See generally Hudson, Police Review Boards and Police Accountability, 36 Law \& Contemp. Probs. 515 (1971) (studies of New York City and Philadelphia).

263. Schwartz, Reaching Systemic Police Abuses-The Need for Civilian Investigation of Misconduct: $A$ Response to Wayne Kerstetter, in Police Leadership in America: Crisis and Opportunity 187 (W. Geller ed. 1985).

264. H. Goldstein, supra note 257, at 174.

265. Kerstetter, Who Disciplines the Police? Who Should?, in Police Leadership in America, supra note 263 , at 149 .

266. See generally E. Schur, supra note 19; Kadish, supra note 38; F. All.en, supra note 39.

267. See generally Wilson \& Kelling, Broken Windows, Atlantic Monthly, March, 1982, at 34.

268. J. Skolnick \& D. Bayley, supra note 20, at 214-29.

269. See, e.g., id. at 121-22.

270. Skolnick, supra note 22, at 1151 .

271. The Knapp Commission Report on Police Corruption, supra note 29, at 91-115. 
associated with the profits from drug-related enterprises. ${ }^{272}$ This has naturally added a new dimension to the corruption problems related to drugs. What is the implication of the possibility that a free line of cocaine from a friend may have replaced the free cup of coffee as the most important precipitating event on the slippery slope toward corruption?

The official reaction to cocaine use by police officers, certainly reasonable because of the drug's illegal nature, may have created vulnerabilities to corruption. By official treatment of cocaine use as a deviant category, police officials may unintentionally open the door for rationalization of accepting money from drug dealers. If cocaine use was treated more like alcohol issues, intermediate steps of corruption may be removed. The lesson of overdramatizing the marijuana use issue is still fresh in many memories. The campaign against drugs may cause problems when individual officers use cocaine on occasion or know others who use it recreationally.

Another illegal drug, heroin, continues to confound anti-corruption efforts. The success of lower-end heroin market enforcement complicates matters. Because local police, often young and relatively new on the force, have more opportunities for selective enforcement and because they have difficulty in seeing their efforts as equal in importance to making major cases against large-scale dealers, they may be open to corruptive influence. At the same time, endemic problems from the use of informants in drug control raise complicating factors for street police. ${ }^{273}$

Ironically, some of the corruption revelations may be explained as a result of a historically specific combination of two cohort-related phenomena: the willingness to blow the whistle and demand integrity in government and the problems of certain kinds of drug use opening the way to corrupt careers. A police officer who is twenty-two years old in 1987 was in first grade when Roe v. Wade ${ }^{274}$ was decided and the Watergate break-in took place. He was in the early years of elementary school when the Democratic party included marijuana decriminalization in their platform debates. ${ }^{275}$

On a more symbolic level, the unwillingness of individual police officers, or some police departments, to acknowledge the legitimacy of gays and lesbians, even after the enactment of specifically designed anti-discrimination ordinances, ${ }^{276}$ can cause police to subject gay bars to shakedowns differentially. In each of the five cities examined, gay rights ordinances have been offered, gay or AIDS victimization issues have been central, and some amount of police issues related to gay bars have surfaced.

Gambling, traditionally the quintessential "clean graft," has changed dramatically in the past decade, as several states have approved lotteries or

272. 2 MAYOR's AdvisOry RePORT, supra note 153, at 24.

273. J. Skolnick, supra note 22, at 1150-51; P. ReUTer, supra note 52, at 194-97; see also M. MOORE, Buy ANd Bust 126 (1977).

274. Roe v. Wade, 410 U.S. 113 (1973).

275. P. Anderson, High in America 5 (1981).

276. Meeker, Dombrink \& Geis, supra note 50, at 756. 
parimutuel wagering. ${ }^{277}$ At the same time, the ambivalence of the public and of officials to illegal gambling has increased. ${ }^{278}$ Certainly, more research needs to be done to determine the actual relationship of illegal gambling to organized crime. Most parties to the debate are generally interested parties, ${ }^{279}$ and a neutral data base would help inform decisionmaking in that area. Earlier findings, showing that police perceive the seriousness of illegal gambling as a product of organized crime's role in it, and that many police favor the legalization of gambling, are dated. ${ }^{280}$ Reuter's data from New York City, challenging the "Kefauver orthodoxy" of illegal gambling as important and lucrative for major organized crime groups, ${ }^{281}$ could be extended to other cities. The President's Commission on Organized Crime ${ }^{282}$ collected data from local law enforcement agencies which indicate the continued allegiance to such an orthodoxy. These data do not aid in any widescale attempt to embrace legalization as the leading alternative to the current level of illegal gambling prevention. ${ }^{283}$ More research also needs to be done to examine the competitiveness of state-run gambling with illegal forms. Many have suggested that legal counterparts cannot effectively compete, because the illegal forms offer more credit, hours, phones, and wagers. ${ }^{284}$

The Wilson and Kelling argument on "broken windows," and the effect of disorder on crime, challenges policing priorities that are informed by prosecutorial policies or by citizen response to seriousness measures. ${ }^{285}$ Their rationale for giving attention to offenses of relatively low seriousness because such offenses can encourage more serious crimes offers another complication in any effort to reduce the ambivalence related to vice. ${ }^{286}$

On the control side, deterrence and discovery issues related to preventing corruption may be effectively separated. Deterrence may limit the effectiveness of other policing mandates, but may nonetheless be less expensive than employing full observation, reporting, and discovery mechanisms. The deployment of the latter may affect morale enough to encourage cynicism, possibly contributing to receptiveness to corruption.

Some responses that emanate from the rank and file would have greater weight, but might also be limited by street officers' beliefs that corruption publicity and control is a political reaction to a media problem. ${ }^{287}$ Where corruption is less than systemic but still tacitly condoned through a code of

277. J. Rosecrance, Gambling Without Guilt 4-5 (1988).

278. See J. Meeker \& J. Dombrink, supra note 53, at 3.

279. Id. at 8 .

280. Pratter \& Fowler, supra note 53.

281. P. REUTER, supra note 52 , at 181-87.

282. J. Meeker \& J. Dombrink, supra note 53, at 2.

283. Id. at 96 .

284. Wilson \& Kelling, supra note 267.

285. Bureau of Justice Statistics, U.S. Dep't of Justice, Report to the Nation on Crime and JUSTICE 4-5 (OCt. 1983).

286. J. Meекer \& J. Dombrink, supra note 53, at 96; see generally Skolnick, supra note 26.

287. M. PUNCH, supra note 21, at 200. 
silence, it may be susceptible to efforts to train and preach against it, something short of "[j]ust say 'No' to corruption opportunities."

The momentum of the government undercover sting operations, like ABSCAM, after faltering, may have gathered steam in recent years with municipal corruption investigations in New York City, Chicago, Philadelphia, and elsewhere, especially after the initiation of the Iran-Contra investigation and hearings. ${ }^{288} \mathrm{~A}$ phenomenon like the post-Watergate emphasis on institutional integrity may emerge. To the extent that federal prosecutors, as outsiders, are able to act more effectively than their local counterparts, they are likely to be the creators of scandal. They tend towards an overreliance upon prosecution and its deterrent capacity and are less suited to suggest and implement institutional reforms. ${ }^{289}$

Another federal-local police cooperation issue is relatively new. The issue is a product of federal regulations which allow for the sharing of forfeited criminal assets with contributing local police agencies. ${ }^{290}$ How much local partnership efforts in the asset forfeiture area increase local police participation in drug control efforts of a previously exclusively federal nature will be instructive in determining whether increase or decrease in corruption opportunities results. More contact with drug dealers might lead to an increase in corruption. Conversely, less frustration on the part of local police with perception of their status as junior actors in the drug wars could decrease corruption. In addition, more careful oversight by other cooperative federal agencies could reduce corruption.

Gardiner's “Wincanton" findings remain valuable because they pointed to the contradiction of high tolerance of illegal activity (gambling) and low tolerance of police corruption. ${ }^{291}$ In Philadelphia, the survey conducted for the Philadelphia Police Study Task Force found that the public thought highly of the police, yet also thought that the police might succumb to corruption and underenforcement in vice areas. ${ }^{292}$ This response to corruption revelation is entirely appropriate in a city with a high crime rate, fiscal problems, and a generally high level of police delivery of services.

An emphasis on reducing corruption might deter effective and preferable policing of major crimes in a number of ways. It might make police wary of any contacts with potential informants or witnesses who are involved in vice, limit the aggressiveness of successful police who are both corruption-prone and courageous in their other policing efforts, ${ }^{293}$ or make police officers fear

288. G. Caplan, abSCaM Ethics: Moral Issues and Deception in Law Enforcement (1983); President's Special Review Board, The Tower Commission Report (1987).

289. Ruff, Federal Prosecution of Local Corruption: A Case Study in the Making of Law Enforcement Policy, 65 Georgetown L.J. $1171,1171-72$ (1977).

290. U.S. Dep't of Justice, Asset Forfeiture Office, Criminal Division, Dep't of Justice Forfeiture MANUAL 127-28 (1987).

291. J. GARDINER, supra note 12, at 56.

292. Philadelphia Police Study Task Force, supra note 79 , at $164,168-71$.

293. M. PUnCh, supra note 21, at 204. 
that their partners are field associates, thus reducing trust and exposing both police and citizens to increased danger.

Field' associates programs have been controversial. Anthony Bouza, former New York Police Department Commander, has called the field associates program the "'most effective tool for controlling a police department." "294 In contrast, Phil Caruso, the President of the New York Police Department Police Benevolent Association, claims "“ ' $t$ ] his kind of spying within the ranks is very demoralizing and casts an aura of suspicion on your brother officer.' . . . You don't know who you can trust and who you can't trust."295 Representatives of the Philadelphia Fraternal Order of Police have complained that officers who are not part of the program might be unduly ostracized. They also suggested that veterans would assume that any recruit coming out the academy is a field associate and would treat that recruit accordingly. "'It virtually seals the fate of the rookies. . . Ninety-five percent of the rookies who hit the streets will not be field associates, . . . but they are all going to get a frosty reception." "296 According to this view, rookies, who must normally contend with a potentially hostile or indifferent environment, could suffer added strain which could lead to poor socialization, increased danger to police, and less effective policing overall.

Finally, the demands of community-based policing complicate the police patrol organization which attempts to prevent rootedness of corruption in individual units or geographical areas. This conflict caused New York Police Commissioner Ward to back down from plans to rotate police officers on a regular basis to prevent the entrenchment of corruption. ${ }^{297}$

Skolnick's and Bayley's suggestions about the appropriateness of various forms of policing strategies and their deployment in specific communities indicate that no conclusions can be easily applied to any of the five cities mentioned, or any other particular city, for that matter. ${ }^{298}$ They believe that policing will probably be more effective to the extent it relies on a mix of strategies appropriate to each neighborhood rather than relying on the single complaint strategy as the primary approach for all neighborhoods. ${ }^{299}$ Further, they argue that community police commanders should be given the authority to conduct informal experiments with different strategies to determine the optimal fit between the unique characteristics of the community and the mixture of policing techniques. ${ }^{300}$ As community-oriented policing programs expand, the need for responsiveness among police organizations becomes a key factor in the ability of contemporary police departments to

294. Hepp, Police Spying on Police: Quiet and Controversial, Philadelphia Inquirer, Aug. 11, 1986, at BO1, col. 2.

295. Id.

296. Id.

297. See Purdum, supra note 187

298. J. SKOLNick \& D. Bayley, supra note 20, at 210-29.

299. Id.

300. Id. 
accommodate changes in crime, disorder, funding, and policing techniques in the 1980's. ${ }^{301}$

In a less instrumental sense, police corruption control represents a range of strategies aimed at installing professionalism, high morale, and commitment to innovation in police organizations. As John Kaplan points out, the very police organizations that may be revealed as corrupt are also typified by a level of organizational ossification that limits the introduction of innovative policing strategies and the elevation of officials who are not protective of the corruption and rigidity of the existing order. ${ }^{302}$ Policecommunity relations and citizen respect for police are adversely affected by police corruption. The events of the past decade have further confounded the ambivalence surrounding the policing of vice. New situations, new cohort attitudes, new policing demands, and more decriminalization have muddied the waters in the vice enforcement area. With this ambivalence of innovative policing strategies, yet another powerful reason for societal resolution of the legal treatment of vice has been created.

301. Id.

302. Comments of John Kaplan, Professor of Law, Stanford University, at Law and Contemporary Problems Symposium on Vice at Duke Law School, Durham, North Carolina (June 5-6, 1987). 